
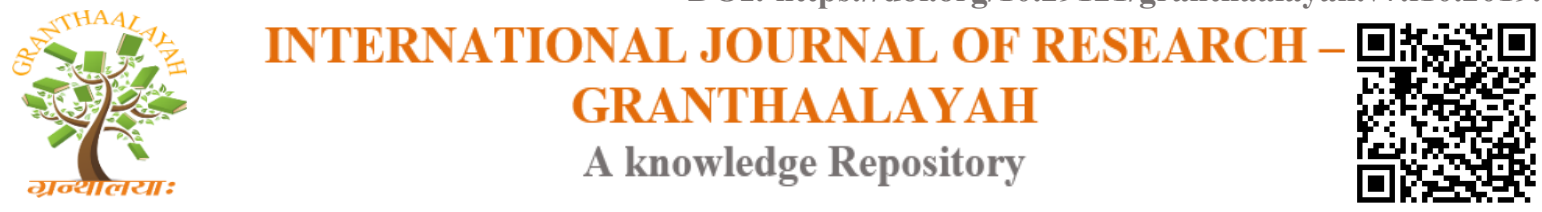

Social

\title{
AWARENESS OF B.A / B.SC. ED INTEGRATED COURSES AMONG THE HIGHER SECONDARY STUDENTS
}

\author{
S. Swarnalatha ${ }^{1}$, Dr. A. Veliappan ${ }^{2}$ \\ ${ }^{1}$ M.Ed. Student, Department of Education, Manonmaniam Sundaranar University, Tirunelveli, \\ Tamilnadu, India \\ ${ }^{2}$ Assistant Professor, Department of Education, Manonmaniam Sundaranar University, \\ Tirunelveli, Tamilnadu, India
}

\begin{abstract}
In order to investigate the awareness of B.A/B.Sc.Ed integrated Courses among the higher secondary students, a sample size of 309 higher secondary students were selected by adopting a simple random sampling technique from the Tirunelveli district, Tamilnadu. Awareness of B.A/B.Sc.Ed integrated courses were assessed with the help of 'Scale on Awareness of B.A/B.Sc.Ed integrated courses'. A descriptive survey method was adopted for the study and the data obtained from the survey was analyzed using percentage analysis, t-test, and F-test. The findings of the study depicted that there is a low level of awareness of B.A/B.Sc.Ed integrated courses among the higher secondary students. Moreover, there is no significant difference in awareness of B.A/B.Sc.Ed integrated courses among the higher secondary students with regard to gender and locality of the students. But it is found that there is significant difference in awareness of B.A/B.Sc.Ed integrated courses among the higher secondary students with regard to their age group.
\end{abstract}

Keywords: Awareness; Integrated Courses; Higher Secondary Students.

Cite This Article: S. Swarnalatha, and Dr. A. Veliappan. (2019). "AWARENESS OF B. A/B.SC.ED INTEGRATED COURSES AMONG THE HIGHER SECONDARY STUDENTS." International Journal of Research - Granthaalayah, 7(10), 216-221. https://doi.org/10.29121/granthaalayah.v7.i10.2019.389.

\section{Introduction}

Integrated Teacher Education Programme (ITEP) is one of the initiatives by National Council for Teacher Education (NCTE), which aims to bring a qualitative change in the teacher training for the better schools system. It also focuses to assimilate best practices of teacher education in the world. The programme offers a curriculum that has a fine balance of theory and practice. It is imbibing the students with quality education and training in liberal discipline of knowledge and field of education. The major subjects in the programme will include Mathematics, Science, Social Sciences and Humanities etc. integrated teacher education programmes offered by the regional 
institutes of education for many years have self-recognition and accreditation (Mohan, 2013). NCTE sources said that revamped syllabus for the integrated B.A.Ed and B.Sc.Ed is being more practical oriented. In November 2014, NCTE had unveiled new models for teacher training courses including the two-year B.Ed after graduation, replacing the one-year course and the four-year integrated course after class XII. However, it needs to be pointed out that the focus of making the four year programme resulting in a composite degree involving three year of B.A/B.Sc and one year of B.Ed and seeking equivalence of the programme (Siddiqui, Sharma \&Arora, 2009). Integrated curriculum provides opportunities for more relevant, less fragmented, and more stimulating experiences for learners (Furner \& Kumar, 2007). The four-year courses were innovative courses in teacher preparation with view to produce highly motivated teachers of quality by integrating the subject matters with professional education and training them in pedagogy and subject areas over a long period (Panda \& Tewari, 2009).

This is not just a course, but also a pillar of the society. Four years well spent on the course promise bright future forever. The integrated courses that ensure personal, professional as well as social growth do not think twice and bag the opportunity by enrolling in the course (Szarek et al., 2016). Moreover, accrediting bodies require integration in developing a coherent and coordinated curriculum. Learning in an integrated course is not an end in itself but is ultimately a vehicle for knowledge essential for personal and social transformation. "Integrated curriculum is an approach to learning that consciously blends and applies content from more than one discipline to better examine a central theme, issue, problem, topic, or experience and encourages "disciplinary contamination" where subjects are integrated and interrelated to address relevant issues of current time and context" (Yadav \& Ojha, 2016).

\section{Objectives of the Study}

The objectives of the present study are as follows.

1) To find out the level of awareness of B.A/B.Sc.Ed integrated courses among the higher secondary students.

2) To find out the level of awareness of B.A/B.Sc.Ed integrated courses among the higher secondary students with regard to personal variables.

3) To find out the significant of difference, if any, in awareness of B.A/B.Sc.Ed integrated courses among the higher secondary students with regard to personal variables namely gender, age and locality of the students.

\section{Hypotheses of the Study}

The hypotheses of the present study, which are framed according to the objectives are stated as below.

1) There is no significance of difference in awareness of B.A/B.Sc.Ed integrated courses among the higher secondary students with regard to gender.

2) There is no significance of difference in awareness of B.A/B.Sc.Ed integrated courses among the higher secondary students with regard to their age group.

3) There is no significance of difference in awareness of B.A/B.Sc.Ed integrated courses among the higher secondary students with regard to locality of the students. 


\section{Method of the Study}

The survey method was adopted for this study.

\section{Sample of the Study}

A sample of 309 higher secondary students were selected by simple random sampling technique from government, government aided and private schools in Tirunelveli District, Tamilnadu.

\section{Tool Used}

"Scale on Awareness of B.A/B.Sc.Ed Integrated Courses" constructed and validated by the investigator. The content validity of the scale, which consist of 31 items, was established with the help of experts. The present study employed Cronbach's Alpha test, the reliability coefficient was found to be 0.864 , and the tool is more reliable.

\section{Statistical Techniques Used}

The statistical techniques applied for the study are percentage analysis, t-test and F-test.

\section{Data Analysis}

Table 1: Level of Awareness of B.A/B.Sc.Ed Integrated Courses among the Higher Secondary Students

\begin{tabular}{|l|l|l|l|l|l|}
\hline \multicolumn{5}{|c|}{ Level of Awareness of B.A/B.Sc.Ed Integrated Courses } \\
\hline Low & Moderate & High \\
\hline N & $\%$ & N & $\%$ & N & $\%$ \\
\hline 149 & 48.22 & 103 & 33.33 & 57 & 18.45 \\
\hline
\end{tabular}

The above table shows that two-fourth of the higher secondary students (48.22\%) have low level of awareness of B.A/B.Sc.Ed integrated courses.

To find out the level of awareness of B.A/B.Sc.Ed integrated courses among the higher secondary students with regard to Personal Variables

Table 2: Level of Awareness of B.A/B.Sc.Ed Integrated Courses among the Higher Secondary Students with regard to Personal Variables

\begin{tabular}{|l|l|l|l|l|l|l|l|}
\hline Personal Variables & \multirow{2}{*}{ Category } & \multicolumn{2}{l|}{ Low } & \multicolumn{2}{l|}{ Moderate } & \multicolumn{2}{l|}{ High } \\
\cline { 3 - 8 } & & $\mathbf{N}$ & $\mathbf{\%}$ & $\mathbf{N}$ & $\mathbf{\%}$ & $\mathbf{N}$ & $\mathbf{\%}$ \\
\hline \multirow{3}{*}{ Gender } & Male & 61 & 48.03 & 40 & 31.49 & 26 & 20.47 \\
\cline { 2 - 8 } & Female & 88 & 48.35 & 63 & 34.61 & 31 & 17.03 \\
\hline \multirow{4}{*}{ Age } & 15 & 29 & 56.86 & 18 & 35.29 & 4 & 7.84 \\
\cline { 2 - 8 } & 16 & 94 & 47.95 & 68 & 34.69 & 34 & 17.34 \\
\cline { 2 - 8 } & 17 & 26 & 41.93 & 17 & 27.42 & 19 & 30.64 \\
\hline \multirow{2}{*}{ Locality of the Students } & Rural & 109 & 46.98 & 80 & 34.48 & 43 & 18.53 \\
\cline { 2 - 8 } & Urban & 40 & 51.94 & 23 & 29.87 & 14 & 18.18 \\
\hline
\end{tabular}


The above table shows that more than two-fourth of the higher secondary students have low level of awareness of B.A/B.Sc.Ed integrated courses with regard to personal variables namely gender, age and locality of the students.

Ho1: There is no significant difference between male and female higher secondary students with regard to their awareness of B.A/B.Sc.Ed integrated courses

Table 3: Significance of difference in Awareness of B.A/B.Sc.Ed Integrated Courses among the Higher Secondary Students with regard to Gender

\begin{tabular}{|l|l|l|l|l|l|}
\hline Gender & $\mathbf{N}$ & Mean & Standard Deviation & t-value & p-value \\
\hline Male & 127 & 81.35 & 11.308 & \multirow{2}{*}{0.971} & $0.144^{\mathrm{NS}}$ \\
\hline Female & 181 & 81.39 & 9.875 & & \\
\hline
\end{tabular}

NS - Not Significant at $5 \%$ level

In the above table, since the p-value $(=0.144)$ is greater than 0.05 , hence the null hypothesis is $A C C E P T E D$ at $5 \%$ level of significance. It shows that there is no significant difference in awareness of B.A/B.Sc.Ed integrated courses among the higher secondary students with regard to Gender.

$\boldsymbol{H}_{0}$ 2: There is no significant difference in awareness of B.A/B.Sc.Ed integrated courses among higher secondary students with regard to their age group.

Table 4: Significance of difference in Awareness of B.A/B.Sc.Ed Integrated Courses among the Higher Secondary Students with regard to their age group

\begin{tabular}{|l|l|l|l|l|l|}
\hline Source of Variation & Sum of Squares & df & Mean square & F-value & p-value \\
\hline Between Groups & 1183.251 & 2 & 591.625 & & \\
\cline { 1 - 3 } Within Groups & 32494.154 & 306 & 106.190 & & \\
\hline Total & 33677.405 & 308 & & 5.571 & $0.004 * *$ \\
\hline
\end{tabular}

** - Significant at $1 \%$ level

In the above table, since the p-value $(=0.004)$ is lesser than 0.01 , the null hypothesis is NOT $A C C E P T E D$ at $1 \%$ level of significance. It shows that there is significant difference in awareness of B.A/B.Sc.Ed integrated courses among the higher secondary students with regard to their age group.

Since there is significant difference, Post Hoc test is attempted. The Scheffe test results are tabulated below.

Table 5:

\begin{tabular}{|c|c|c|c|c|c|c|}
\hline \multirow[t]{2}{*}{ Variable } & \multicolumn{3}{|c|}{ Age } & \multirow{2}{*}{$\begin{array}{c}\text { Mean } \\
\text { Differences }\end{array}$} & \multirow{2}{*}{$\begin{array}{l}\text { Standard } \\
\text { Error }\end{array}$} & \multirow{2}{*}{$\begin{array}{c}\mathbf{p -} \\
\text { value }\end{array}$} \\
\hline & 15 & 16 & 17 & & & \\
\hline \multirow{3}{*}{$\begin{array}{l}\text { Awareness of B.A/B.Sc., } \\
\text { Ed Integrated Courses }\end{array}$} & 77.73 & 81.40 & & 3.67 & 1.620 & $0.078^{\mathrm{NS}}$ \\
\hline & & 81.40 & 84.23 & 2.83 & 1.502 & $0.173^{\mathrm{NS}}$ \\
\hline & 77.73 & & 84.23 & 6.50 & 1.948 & $0.004^{* *}$ \\
\hline
\end{tabular}


The above Scheffe test results reveal that the higher secondary students aged 16 and 17years are better than those aged 15 years in awareness in B.A/B.Sc.Ed integrated courses.

$\boldsymbol{H}_{0}$ 3: There is no significant difference between rural and urban area higher secondary students with regard to their awareness of B.A/B.Sc.Ed integrated courses

Table 6: Significance of Difference in Awareness of B.A/B.Sc.Ed Integrated Courses among the Higher Secondary Students with regard to Locality of the Students.

\begin{tabular}{|l|l|l|l|l|l|}
\hline Locality of the Students & $\mathbf{N}$ & Mean & Standard Deviation & t-Value & p-Value \\
\hline Rural & 232 & 81.37 & 10.762 & & \\
\hline Urban & 77 & 81.34 & 9.543 & 0.980 & 0.357 NS \\
\hline
\end{tabular}

NS - Not Significant

In the above table, since the p-value $(=0.357)$ is greater than 0.05 , hence the null hypothesis is $A C C E P T E D$ at $5 \%$ level of significance. It shows that there is no significant difference in awareness of B.A/B.Sc.Ed integrated courses among the higher secondary students with regard to locality of the students.

\section{Findings of the Study}

1) Two-fourth of higher secondary students had low level of Awareness of B.A/B.Sc.Ed integrated courses.

2) Two-fourth of higher secondary students had low level of Awareness of B.A/B.Sc.Ed integrated courses with regard to personal variables namely gender, age and locality of the student.

3) There was no significant difference in awareness of B.A/B.Sc.Ed integrated courses among higher secondary students with regard to gender.

4) There was no significant difference in awareness of B.A/B.Sc.Ed integrated courses among higher secondary students with regard to locality of the students.

5) The higher secondary students aged 16 and 17 years are better than who aged 15 in awareness of B.A/B.Sc.Ed integrated courses.

\section{Recommendations}

In the modern world, everyone likes to do work fast within short time. At the same think B.A/B.Sc.Ed integrated courses is four year when comparing the traditional two-year B.Ed course. In particularly, most of the higher secondary students have no aware of the integrated courses. Awareness without action is worthless. The ultimate value of life depends upon awareness and the power of contemplation rather than mere survival. The school management should provide awareness programme about integrated courses with the help of teachers, teacher educators and special invitees etc. Not only should the students, the parents also be provided with awareness programme about the integrated courses. 


\section{References}

[1] Furner, J. \& Kumar, D. (2007). The mathematics and science integration argument: A stand for teacher education. Eurasia Journal of Mathematics, Science \& Technology Education, 3(3), 185189.

[2] Hammond, L.D. \& Liberman, A. (2012). Teacher education around the world, Newyork: Routledge Taylor \& Francis Group.

[3] Kumar, R. (2011). Research methodology (3rd ed.). New Delhi: Sage Publications India Pvt Ltd.

[4] Mohan, R. (2013). Teacher education. New Delhi: PHI Learning Private Limited.

[5] Panda, B.N \& Tewari, A.D. (2009). Teacher education. New Delhi: APH Publishing Corporation.

[6] Siddiqui, M.A. \& Sharma, A.K. \& Arora, G.L. (2009). Teacher education reflections towards policy formulation. New Delhi: National Council for Teacher Education.

[7] Szarek, J.L \& Boardman, J.M \& White, M. \& Holt, J.T (2016). Integrated and flipped: 5 year's experience of integrating active learning in an integrated course. International Association of Medical Science Educators26, 159-167. doi:10. 1007/s40670- 015-0214-7.

[8] Yadav, D. \& Ojha, N.C. (2016). Integrated teacher education curriculum: A delphi study. Asian Journal of Multidisciplinary Studies, 4(13), 93-99.

*Corresponding author.

E-mail address: swarnalathatsn@ gmail.com 